J. Perinat. Med.

17 (1989) 237

\section{Fetal bradycardia in labor}

\author{
Volker Michael Roemer and Ulrike Fritz \\ Department of Gynecology and Obstetrics, Detmold County Hospital, Detmold, \\ West Germany
}

\section{Introduction}

Monitoring of fetal heart rate and frequency of uterine contractions during labor (cardiotocography) has been established in German-speaking countries for more than 20 years. Despite criticism $[1,2,3,4,12,13]$, it is of proved benefit. Occasionally, interpretation of certain fetal heart rate patterns gives rise to difficulties. In contrast to ECG analysis, which complies with exact criteria that are relatively easy to learn, fetal heart rate patterns are difficult to interpret. This applies for example to the evaluation of deceleration patterns or to terminal bradycardia. Experience shows that both phenomena are overestimated, i. e. the obstetrician feels compelled to end labor quickly in the occurrence of decelerations and/or phases of bradycardia. This is the more understandable since not only the ostensibly endangered integrity of the health of the unborn baby is involved, but also the potential legal consequences.

In the following paper, a cardiotocographic phenomenon which sometimes leads to inadequate reactions in the labor room will be analysed in detail: terminal bradycardia.

\section{Methods}

This study is based on 12,145 intrapartal cardiotocograms from the Tübingen University Division of Gynecology and Obstetrics and some cardiotocograms from the Gynecology and Obstetrics Division at the Detmold County Hospital. All CTG's were registered routinely via a scalp electrode. Qualitatively unsatisfactory CTG's were excluded. Altogether, 135 heart rate curves were found in which terminal bradycardias suddenly occurred before birth. A constant frequency level below 120 beats/minute during the phase of bradycardia and a normal cardiotocogram free of decelerations before the fall in frequency were decisive for the selection.

Heart rate curves of 45 fetuses which were selected from 1,225 CTG's in which neither decelerations nor falls in frequency had occurred during the expulsion period served as control population. The cardiotocogram of these fetuses had to have been completely normal for at least 30 minutes before birth. All deliveries which had to be terminated by cesarian section were not evaluated. The basal frequency level was registered in such a way that the mean frequency was estimated by eye over a period of 30 seconds. The frequency levels of 10 and a half minutes before the beginning of bradycardia and the frequency values of the terminal bradycardia itself were analysed. An analogous procedure was applied in the control population. The rate of paper speed of the cardiotocograms was $2 \mathrm{~cm} / \mathrm{min}$ in all cases. The frequency and amplitude of oscillation were not considered, since this would have required an absolutely flawless, i. e. interference-free beat-to-beat registration, which was actually present only in very few recordings. The figures of the basal frequency were evaluated with electronic aids on the basic of important clinical data from the mother and child. The large IBM system of the Tübingen Medical Faculty (370/4381) was available to us. The Student Z-test, the Chi-square test, rank correlation analysis according to Kendall as well as correlation analysis according to Pearson were used for statistical analysis. 
Table I. Clinical variable

\begin{tabular}{|c|c|c|c|c|c|c|}
\hline \multirow{2}{*}{$\begin{array}{l}\text { Variable } \\
\text { Amniotic fluid }\end{array}$} & \multicolumn{3}{|c|}{$\begin{array}{l}\text { Terminal Bradycardia } \\
\mathrm{n}=135\end{array}$} & \multicolumn{3}{|c|}{$\begin{array}{l}\text { Normocardia } \\
\mathrm{n}=45\end{array}$} \\
\hline & & & & & & \\
\hline $\begin{array}{l}\text { Clear } \\
\text { Containing meconium }\end{array}$ & \multicolumn{3}{|l|}{$\begin{array}{r}85,9 \% \\
8,1 \%\end{array}$} & \multicolumn{3}{|l|}{$\begin{array}{r}86,7 \% \\
2,2 \%\end{array}$} \\
\hline \multicolumn{7}{|c|}{ Rupture of amniotic membranes } \\
\hline $\begin{array}{l}\text { Spontaneous } \\
\text { Artificial }\end{array}$ & \multicolumn{3}{|l|}{$\begin{array}{l}59,3 \% \\
40,0 \%\end{array}$} & \multicolumn{3}{|l|}{$\begin{array}{l}82,2 \% \\
17,8 \%\end{array}$} \\
\hline \multicolumn{7}{|l|}{ Oxytocic medication } \\
\hline \multirow[t]{2}{*}{$\begin{array}{l}\text { None } \\
\text { Yes }\end{array}$} & \multicolumn{3}{|l|}{$\begin{array}{l}68,9 \% \\
31,1 \%\end{array}$} & \multicolumn{3}{|l|}{$\begin{array}{l}75,6 \% \\
24,4 \%\end{array}$} \\
\hline & $\overline{\mathbf{X}}$ & $\mathrm{SD}$ & $\mathbf{N}$ & $\overline{\mathrm{X}}$ & SD & $\mathbf{N}$ \\
\hline $\begin{array}{l}\text { Age } \\
\text { Parity } \\
\text { Week of pregnancy } \\
\text { Weight }(\mathrm{g}) \\
\text { Length }(\mathrm{cm})\end{array}$ & $\begin{array}{r}27,5 \\
2,0 \\
40,2 \\
3385 \\
50,5\end{array}$ & $\begin{array}{r}4, \\
0,5 \\
1,3 \\
394 \\
1,5\end{array}$ & $\begin{array}{l}135 \\
135 \\
135 \\
135 \\
135\end{array}$ & $\begin{array}{r}26,6 \\
1,9 \\
40,1 \\
3452 \\
51,5\end{array}$ & $\begin{array}{r}3,9 \\
1,0 \\
1,0 \\
434 \\
1,9\end{array}$ & $\begin{array}{l}45 \\
45 \\
45 \\
45 \\
45\end{array}$ \\
\hline
\end{tabular}

\section{Results}

The evaluation criteria specified above were fulfilled by 135 of 12,145 cases $(1.1 \%)$, i. e. terminal bradycardia which occurs abruptly is only to be reckoned with in about $1 \%$ of all deliveries.

Table I shows that there were some clinical differences in the bradycardiac and normocardiac population: the high percentage of amniotomies (40\%) in the bradycardia population and the raised percentage of amniotic fluid with a high meconium content $(8.1 \%)$ is striking. These figures were $17.8 \%$ and $2.9 \%$ respectively in the normocardiac group. Other authors and we ourselves have already pointed out the potential danger of premature amniotomy in other publications $[5,6]$. This potential danger is confirmed once more in the present study.

Table II shows sthat striking differences naturally occurred in the clinical parameters: a forceps delivery was carried out in $20 \%$ in the group with terminal bradycardia, whereas this was necessary in "only" $13.3 \%$ of cases in the normocardiac group. However, this difference is not statistically significant. The differences in the frequency of primiparity were also fortuitous. As expected, the percentage of fetal umbilical cord coiling (table III) was markedly higher in the population with
Table II. Data on delivery

\begin{tabular}{|c|c|c|c|c|}
\hline \multirow[t]{2}{*}{ Variable } & \multicolumn{2}{|c|}{$\begin{array}{l}\text { Terminal } \\
\text { bradycardia } \\
\mathrm{N}=135\end{array}$} & \multicolumn{2}{|c|}{$\begin{array}{l}\text { Normo- } \\
\text { cardia } \\
\mathrm{N}=45\end{array}$} \\
\hline & $\mathbf{N}$ & $\%$ & $\mathbf{N}$ & $\%$ \\
\hline Spontaneous delivery & 108 & 80,0 & 39 & 86,7 \\
\hline Forceps delivery & 27 & 20,0 & 6 & 13,3 \\
\hline Primipara & 41 & 30,4 & 20 & 44,4 \\
\hline Duration of pregnancy $<38$ & 86 & 4,4 & 1 & 2,2 \\
\hline Weight $<2.500 \mathrm{~g}$ & 1 & 0,7 & - & - \\
\hline
\end{tabular}

Table III. Umbilical cord coiling (\%)

\begin{tabular}{lll}
\hline Umbilical cord coiling & $\begin{array}{l}\text { Terminal } \\
\text { bradycardia } \\
\mathrm{N}=135\end{array}$ & $\begin{array}{l}\text { Normo- } \\
\text { cardia } \\
\mathrm{N}=45\end{array}$ \\
\hline None & 63,0 & 77,8 \\
Present & 37,0 & 22,2 \\
\hline Once around the neck & 25,1 & 17,8 \\
More than once around & 2,2 & 2,2 \\
$\quad$ the neck & 5,2 & 2,2 \\
Around the body & 1,5 & 0,0 \\
Limbs & 3,0 & 0,0 \\
Combination & 37,0 & 22,2 \\
\hline
\end{tabular}


terminal bradycardia (37\%) than in the reference group (22.2\%). This difference is also not statistically significant. Since the duration of the expulsion period may possibly play a role, this data was also calculated: in the group with terminal bradycardia, the mean expulsion period was 20.1 \pm 24.7 minutes; the median was 12 minutes. In the normocardia group, the period was 38.1 \pm 48.1 minutes; the median here was 20 minutes. These differences are probably due to the different proportion of primiparas $(30.4 \%$ versus $44.4 \%)$. Altogether, the duration of the expulsion period itself does not appear to play a causal role.

Figure 1 shows the clinical course of the 135 phases of bradycardia calculated for 30 second intervals: the sudden fall in the fetal heart sounds to about 80 beats/minute is seen. Between the 9 th and the 14 th minute, the standard deviation increases somewhat in places, and the mean heart rate increases, probably due to the greater variation in a small number of cases. Naturally, there were only a few fetuses who had to sustain a bradycardia with a duration of 10 or indeed 15 minutes.

In an analogous representation, figure 2 shows the fetal heart rate of the control group: the mean heart rate in this group was about 140 beats/ minute, and the standard deviations remained constant. Table IV shows a rough frequency distribution for certain frequency bands: mean frequency between 66 and 85 beats/minute occurred most frequently ( $55.5 \%$ of the 135 cases), whereas frequencies below 65 beats/minute were rare $(3.0 \%)$. It is striking that very low frequencies, i.e. values at around 20 or 30 beats/minute were practically never observed. The lowest mean frequency was 55 beats/minute in the present study, and lasted 4.5 minutes. The highest mean frequency was 109 beats/minute, and lasted 7.5 minutes. Extreme bradycardia frequency levels appear to oc-

Table IV. Distribution of the mean $(\overline{\mathbf{x}})$ fetal heart rate during the phase of bradycardia

\begin{tabular}{llc}
\hline Fetal heart rate & \multicolumn{2}{c}{ Terminal bradycardia } \\
& $\mathrm{N}=135$ & \\
\hline Limits & $\mathrm{N}$ & $\%$ \\
\hline$<65$ & 4 & 3,0 \\
$66-85$ & 75 & 55,5 \\
$86-105$ & 54 & 40,0 \\
$>105$ & 2 & 1,5 \\
\hline
\end{tabular}

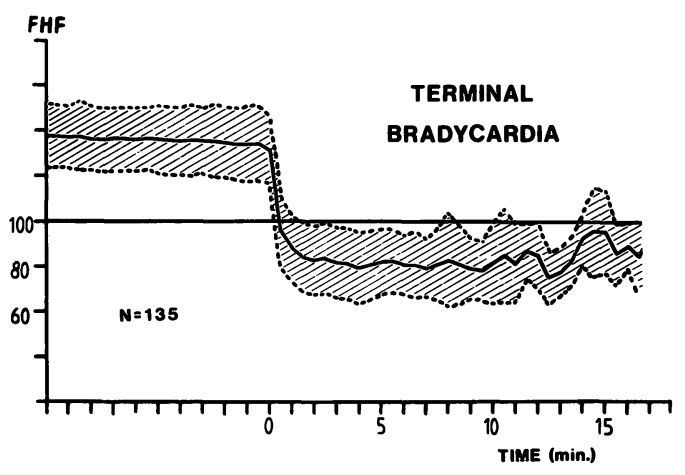

Figure 1. Graphic representation of the fetal heart rate about 10 minutes before the onset of terminal bradycardia and during the phase of bradycardia in $135 \mathrm{fe}$ tuses. The frequency level was registered at intervals of 30 seconds and averaged over all cases.

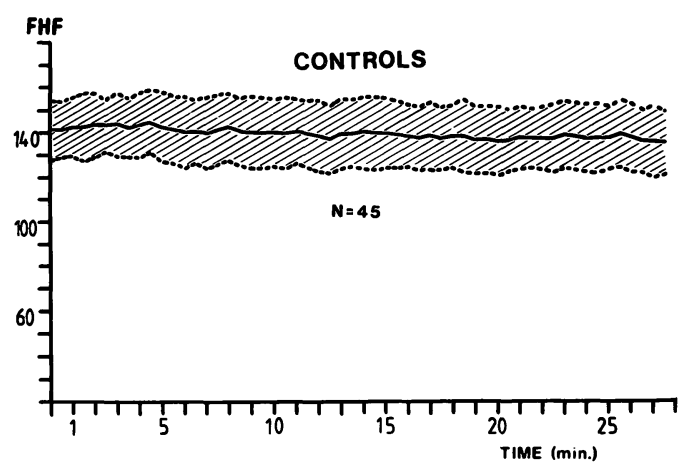

Figure 2. Response of the fetal heart rate during the terminal expulsion period in $\mathbf{4 5}$ fetuses with completely normal cardiotocogram (Control group).

cur only in very severely damaged (i.e. dying) fetuses. The mean heart rate of all fetuses during the phase of bradycardia was $82.6 \pm 9.9$ beats/. minute. The $95 \%$ confidence range was between 81.0 and 84.3 beats/minute.

The mean duration of bradycardia in the overall population was $5.7 \pm 3.1$ minutes $(95 \%$ confidence range: $5.5-6.2$ minutes). In an analogous way, table $\mathrm{V}$ shows a rough distribution structure of the duration of the bradycardia. These figures are naturally affected to an appreciable extent by the obstetric efficiency of a department; they hence do not have any general validity. It is noteworthy that $92.6 \%$ of all bradycardias did not last longer than 10 minutes. The longest phase of bradycardia lasted 18 minutes with a mean frequency of $\mathbf{1 0 2 . 1}$ 
Table V. Distribution of the duration of bradycardia

\begin{tabular}{lll}
\hline Fetal heart rate & \multicolumn{2}{c}{ Terminal bradycardia } \\
& $\mathrm{N}=135$ & \\
\hline Limits (min) & $\mathrm{N}$ & $\%$ \\
\hline$<5$ & 69 & 51,1 \\
$6-10$ & 56 & 41,5 \\
$11-15$ & 7 & 5,2 \\
$16-20$ & 3 & 2,2 \\
\hline
\end{tabular}

beats/minute. The $\mathrm{pH}$ of the fetal blood in the umbilical artery was 7.198, the $\mathrm{pO}_{2}$ was 16.8 $\mathrm{mmHg}$, and the $\mathrm{pCO}_{2}$ was $58.3 \mathrm{mmHg}$. A viable healthy baby was delivered (Apgar scores 9, 10, 10)!

How does terminal bradycardia affect the current blood gases and the $\mathrm{pH}$ in the umbilical arterial and venous blood of the neonate?

Table VI shows the $\mathrm{pH}$ distribution of 120 babies with terminal bradycardia (pertinent data were not available in 15 cases). The mean current $\mathrm{pH}$ in the umbilical artery was $7.261 \pm 0.072$. $\mathrm{pH}$ values under 7.200 were measured in $21.7 \%$ and $\mathrm{pH}$ values under 7.150 were measured in $4.2 \%$. A severe acidosis ( $\mathrm{pH}$ less than 7.100) was not present in any case. A pH value in excess of 7.250 was present in 67 babies with terminal bradycardia $(55.8 \%)$. The current $\mathrm{pH}$ was $7.311 \pm 0.048$ in the control group. The $95 \%$ confidence range was 7.296-7.326. As expected, the difference between the two mean values is highly significant ( $\alpha$ less than 0.001). Only one baby in the control group showed a $\mathrm{pH}$ value of less than $7.22(2.5 \%)$. Analogous conditions were found for the $\mathrm{pH}$ values in the umbilical venous blood, for which there were highly significant differences in the mean values of the two groups.

The clinical condition of the babies evaluated according to the Apgar score 1 minute post partum is shown in table VIII. All Apgar scores were not determined by the obstetrician himself, but by pediatricians trained in neonatalogy.

We were astonished to see that only $5.2 \%$ of all children were slighlty depressed (Apgar score 4-6) and that only one baby gave the impression of severe depression $(0.7 \%)$ in the bradycardia group. All neonates of the bradycardia group recovered quickly, so that the five-minute Apgar scores of both groups were practically identical.
Table VI. Distribution of the $\mathrm{pH}$ values in the blood of the umbilical artery (UA)

\begin{tabular}{lrrrrr}
\hline \multirow{2}{*}{$\mathrm{pH}, \mathrm{UA}$} & \multicolumn{2}{c}{ Frequency } & & \multicolumn{2}{c}{ Cumulative } \\
\cline { 2 - 3 } \cline { 6 - 7 } & $\mathrm{N}$ & \multicolumn{1}{c}{$\%$} & & \multicolumn{1}{c}{$\mathrm{N}$} & \multicolumn{1}{c}{$\%$} \\
\hline $7.100-7.149$ & 5 & 4.2 & & 5 & 4,2 \\
$7.150-7.199$ & 21 & 17.5 & & 26 & 21,7 \\
$7.200-7.249$ & 27 & 22.5 & & 53 & 44,2 \\
$7.250-7.299$ & 31 & 25.8 & & 84 & 70,0 \\
$7.300-7.349$ & 24 & 20.0 & & 108 & 90,0 \\
$7.350-7.399$ & 10 & 8.3 & & 118 & 98,3 \\
$7.400-7.499$ & 2 & 1.7 & & 120 & 100,0 \\
\hline
\end{tabular}

$\mathrm{N}=120$

Table VII. Rank correlation analysis (Kendall)

\begin{tabular}{lcccc}
\hline $\begin{array}{l}\text { Correlated } \\
\text { variable }\end{array}$ & $\tau$ & $\mathrm{z}$ & $\alpha$ \\
\hline $\begin{array}{c}\text { Duration of } \\
\text { brady- } \\
\text { cardia }\end{array}$ & $-\mathrm{pH}, \mathrm{UA}$ & -0.149 & $-2,41$ & $<0.01$ \\
$\begin{array}{c}\text { Duration of } \\
\text { brady- } \\
\text { cardia }\end{array}$ & $-\mathrm{pH}, \mathrm{UV}$ & -0.286 & -4.79 & $<0.001$ \\
$\begin{array}{c}\text { Duration of } \\
\text { brady- } \\
\text { cardia }\end{array}$ & $-\mathrm{BE}, \mathrm{UA}$ & -0.242 & -3.90 & $<0.001$ \\
\hline
\end{tabular}

Table VIII.

\begin{tabular}{lrrrr}
\hline $\begin{array}{l}\text { Apgar index } \\
1 \text { min }\end{array}$ & $\begin{array}{l}\text { Terminal } \\
\text { bradycardia } \\
\mathrm{N}=135\end{array}$ & \multicolumn{2}{l}{ Normocardia } \\
\hline $1-3$ & 1 & $0.7 \%$ & 0 & $0 \%$ \\
$4-6$ & 8 & $5.9 \%$ & 1 & $2.2 \%$ \\
$7-10$ & 126 & $93.3 \%$ & 43 & $97.8 \%$ \\
\hline
\end{tabular}

Eight neonates of the bradycardia group (5.9\%) had difficulties in postpartal adaptation: in four neonates, apnea attacks occurred, two babies had aspirated and one baby temporarily suffered a respiratory distress syndrome. All babies could be discharged in a healthy condition. Absolutely no difficulties in adaptation could be demonstrated in the control population. Minor malformations which occurred in the two groups will not be dealt with in more detail in this context. 
For the clinician, it is important to know how long a fetal bradycardia may last without danger, i.e. how pronounced the correlation is between the duration of bradycardia and the clinical state of the baby. For this purpose, the correlation between different variables of the fetal acid-base balance and the duration of bradycardia was calculated with the rank correlation analysis according to KENDALL. These results are listed in table VII. Highly significant correlations are found between the time factor and the current $\mathrm{pH}$ in the umbilical vein as well as in the umbilical artery and (as expected) also between the time factor and the base excess in the umbilical arterial blood. All other correlations including the correlation with the Apgar index after one minute proved not to be significant.

Finally, it is of interest for the obstetrician to know to what extent the current $\mathrm{pH}$ falls per minute of bradycardia. In such an analysis, assumptions must be made which are not always correct in the individual case: the level of bradycardia, which averages 82 beats/minute in this analysis, must remain unconsidered for methodological reasons. However, it is to be assumed that a bradycardia of around 120 beats/minute has a different diagnostic significance than a bradycardia of around 70 beats/minute. Furhtermore, the uterine contractions or the uterine tonus are doubtless significant. This parameter could not be adequately analysed in the present retrospective study, since corresponding data were not available. Finally, strictly speaking a linear correlation analysis is not admissible, since neither the $\mathrm{pH}$ values nor the time factors have a normal distribution. Nevertheless, it can be inferred from the correlation analysis data that the current $\mathrm{pH}$ in the umbilical artery falls by 0.006 units per minute of bradycardia and that the base excess increases by $-0.340 \mathrm{mEq} / \mathrm{min}$. Analogous calculations for the umbilical vein revealed values of 0.011 and 0.260 . These figures are average values. The variation is relatively great, so that these are only index values, but not index factors for the individual case. Finally, it is once more pointed out that these figures are only valid when the cardiotocogram was completely normal before the beginning of the bradycardia phase, i.e. in concrete terms when the fetus has entered the expulsion period or phase of bradycardia with a current $\mathrm{pH}$ of $7.280-7.300$, and anaerobic glycolysis has not yet startet.

\section{Discussion and conclusions}

Terminal bradycardia rarely occurs e vacuo. Its incidence is only about $1 \%$ of all cases according to this investigation. In fact, a terminal bradycardia almost always occurs in connection with deceleration, especially with variable decelerations which in turn have already had an acidogenetic effect depending on their amplitude and duration, and which is then intensified by terminal bradycardia. Bradycardia resulting from decelerations is generally more frequent. MELCHIOR [7] specifies an incidence of $46 \%$, FISCHER $31 \%$ [8], SCHLOTTER $21.9 \%$ [9] and KüNZEL $18 \%$ [10].

Uniform late decelerations will cause the obstetrician to carry out cesarian section at an early stage. According to our own investigations, slight variable decelerations do not have a significant acidogenetic effect [11], so that the figures communicated here are applicable to a limited extent to the normal expulsion period. The oscillation frequency before and during the phase of bradycardia will be important for the obstetric procedure: if "hypoxic roundings", silent segments of the curve occur, one will have to act more quickly. Whether a blood gas microanalysis is also performed during a phase of bradycardia will depend on the personal skill of the obstetrician and his/her own attitude or training. We ourselves have only rarely done so.

The data presented indicate that contrary to expectations terminal bradycardia within the limits specified is tolerated well by the mature fetus. It should hence not automatically give rise to hazardous delivery maneuvers which may be a greater danger to the mother and child in the individual case than the fetal bradycardia itself. We tend to the view that the impending spontaneous delivery, a delivery which is to be expected in the next two to three uterine contractions, can be waited for as a rule. With a surgical vaginal delivery, it must be borne in mind that time is also required (especially in vacuum extraction), and that an additional analgesia will also be needed in the individual case, so that the baby is in the end not delivered more rapidly than after two to three strong pressing contractions. The definitive appraisal of the size of the baby's head and the soft-tissue resistance will be of crucial significance. In hypertensive uterine contractions and/or tachysystole, an emergency tocolysis and/or cautious pushing up of the head may be attempted in order to improve the circulatory situation of the fetus. 


\section{Summary}

The prognostic significance of terminal bradycardia is analysed in this study. Amongst 12,145 intrapartal directly recorded cardiotocograms, 135 heart rate curves free of deceleration $(1.1 \%)$ were found with an abruptly occurring fetal bradycardia. The mean duration of bradycardia was $5.7 \pm 3.1$ minutes, the mean heart rate during the phase of bradycardia was $86.2 \pm 9.9$ beats/ minute. A premature amniotomy (40\%) was significantly correlated with the bradycardia. The mean $\mathrm{pH}$ in the umbilical arterial blood was $7.261 \pm 0.072$. $\mathrm{pH}$ values of less than 7.200 were measured in $21.7 \%$ and $\mathrm{pH}$ values under 7.150 were measured in $4.2 \%$; a severe acidosis ( $\mathrm{pH}$ less than 7.100) was not present in any

Keywords: Cardiotocogram, terminal bradycardia. case. The fall in fetal $\mathrm{pH}$ in the umbilical arterial blood per minute of bradycardia averages -0.006 units: In the bradycardia group, only $5.2 \%$ of all babies were slightly depressed and only $0.7 \%$ were severely depressed; $5.9 \%$ of the babies had slight difficulties in postpartal adaptation. It is concluded from the data that as a rule the impending spontaneous delivery (head rotated correctly, effective bearing-down efforts) can waited for in the occurrence of terminal bradycardia (without prior decelerations). The fall in heart rate should not automatically occasion the institution of hazardous delivery maneuvers which may entail a greater danger to the mother and baby than the fetal bradycardia itself.

\section{Zusammenfassung}

Zur Kenntnis der fetalen Bradycardie unter der Geburt In dieser Studie soll der Stellenwert einer terminalen Bradycardie analysiert werden.

Unter 12.145 intrapartalen, direkt abgeleiteten Cardiotokogrammen fanden sich 135 dezelerationsfreie Herzfrequenzkurven $(1,1 \%)$ mit einer abrupt auftretenden, fetalen Bradycardie. Die mittlere Bradycardiedauer lag bei 5,7 $\pm 3,1$ Minuten, die mittlere Frequenz während der Bradycardiephase lag bei 82,6 $\pm 9,9 \mathrm{Schläge} / \mathrm{min}$. Mit der Bradycardie war eine vorzeitige Amniotomie (40\%) signifikant assoziiert. Das mittlere $\mathrm{pH}$ im Nabelarterienblut betrug 7,621 $\pm 0,072$. pH-Werte unter 7,200 wurden in $21,7 \%$ und unter 7,150 in $4,2 \%$ gemessen; in keinem einzigen Fall lag eine schwere Azidose $\mathrm{pH}$
$<7,100)$ vor. Der fetale $\mathrm{pH}-\mathrm{Abfall}$ im Nabelarterienblut pro Bradycardie-Minute beträgt im Mittel -0,006 Einheiten. Im Bradycardiekollektiv waren nur $5,2 \%$ aller Kinder leicht und nur 0,7\% schwer deprimiert; $5,9 \%$ der Kinder hatten leichte postpartale Anpassungsschwierigkeiten. Aus den Daten wird der Schluß gezogen, daß beim Auftreten einer terminalen Bradycardie (ohne vorausgegangene Dezelerationen) im Regelfall die anstehende Spontangeburt (Kopf ausrotiert, effektive Preßarbeit) abgewartet werden kann. Der Herzfrequenzabfall sollte nicht automatisch Anlaß sein, gewagte Entbindungsmanöver einzuleiten, die Mutter und Kind unter Umständen mehr belasten als die fetale Bradycardie selbst.

Schlüsselwörter: Cardiotokogramm, terminale Bradycardie.

\section{Résumé}

\section{Bradycardie foetale au cours du travail}

Dans cette étude, on analyse la signification pronostique de la bradycardie terminale. Parmi 12145 cardiotocogrammes enregistrés directement en perpartum, 135 tracés de rythme cardiaque sans décélération $(1,1 \%)$ se sont accompagnés d'une bradycardie fotale de survenue brutale. La durée moyenne de la bradycardie est de 5,7 $\pm 3,1$ minutes, le rythme cardiaque moyen pendant la bradycardie est de $82,6 \pm 9,9$ battements par minute. L'amniotomie prématuré $(40 \%)$ est corrélée de façon significative avec la bradycardie. Le $\mathrm{pH}$ moyen du sang artériel ombilical est de 7,261 $\pm 0,072$. Dans $21,7 \%$ des cas on a mesuré des valeurs du $\mathrm{pH}$ inférieures à 7,2 et dans $4,2 \%$ des valeurs inférieures à 7,15 ; il n'y a pas eu d'acidose sévère ( $\mathrm{pH}$ inférieur à 7,1). La chute par mi- nute du $\mathrm{pH}$ fotal au sang artériel ombilical est en moyenne de 0,006 unités. Dans le groupe avec bradycardie, $5.2 \%$ seulement de tous les enfants ont été légèrement déprimés, et $0,7 \%$ seulement présentaient une dépression sévère; $5,9 \%$ des enfants ont présenté des difficultés légères d'adaptation post-partum. On conclut de ces données qu'en règle générale on peut attendre un accouchement spontané imminent (rotation de la tête accomplie, efforts expulsifs efficaces) en présence d'une bradycardie terminale (en l'absence de décélérations antérieures). La chute du rythme cardiaque ne devrait pas automatiquement être l'occasion de la mise en œuvre de mancuvres dangereuses qui pourraient être à l'origine de périls plus importants pour la mère et l'enfant que la bradycardie fotale elle-même.

Mots-clés: Bradycardie terminale, cardiotocogramme. 


\section{References}

[1] BANTA, HD, SB Thacker: Assessing the costs and benefits of electronic fetal monitoring. Obstet Gynecol Surv (Supp) 34 (1979) 627

[2] BANTA HD, SB THACKER: Fetal monitoring. Letters to the editor. Obstet Gynecol 54 (1979) 667

[3] BAUMGaRTEN K: The benefits and hazards of fetomaternal monitoring. J Perinat Med 9 (1981) 257

[4] Hobbins IC, R Freemann, IT QueEnan: The fetal monitoring debate. Editorial Obstet Gynecol 54 (1979) 103

[5] Wulf KH: Der unzeitige Blasensprung. Arch Gynecol 238 (1885) 217

[6] RoEMER VM, DG KIEBACK: The influence of premature rupture of membranes (PROM) on the course of labor. In: LANGNICKEL D (ed): Problems of the pelvic passage way, Springer, Berlin 1987

[7] MELCHIOR I, N BERNARD: Incidence and pattern of fetal heart alterations during labor. In: KüNZEL W (ed): Fetal heart rate monitoring. Springer, Berlin 1985

[8] Fischer WM, MD Fendel, H Schultze-Mosgau: Fetal heart rate pattern in the second stage of labour and the perinatal outcome. In: STEMBERA et al (eds): Perinatal Medicine, Thieme, Stuttgart 1975

[9] 'SCHLOTTER CM, E JÄGER, G WösSNER, A SCHENK: Fetale Herzfrequenzmuster der Austreibungs- und Preßperiode - Typische Muster, Häufigkeit, Azidoserisiko und Befundung. Arch Gynecol 177 (1979) 55
[10] KÜNZEL W: Die Beziehung zwischen der Herzfrequenz des Feten und dem $\mathrm{pO}_{2}, \mathrm{pCO}_{2}$ und $\mathrm{pH}$ im fetalen Blut während der Eröffnungsperiode und am Ende der Austreibungsperiode. Z Geburtshilfe Perinatol 176 (1972) 275

[11] RoEmer VM, G BrÜHL, S Mitzner, P HeERING, S HEINZL: Die Dezeleration in der direkten Kardiotokographie: Quantitative und qualitative Analyse. In: Schmidt E, JW Dudenhausen, E Saling (eds): Perinatale Medizin. Thieme, Stuttgart 1981

[12] MacDonald D, A Grant, M Sheridan-Pereira, P Boylan, I Chalmers: The Dublin randomized controlled trial of intrapartum fetal heart rate monitoring. Am J Obstet Gynecol 152 (1985) 524

[13] CuRzen P, IS BekIR, DG McLintok, M Pate: Reliability of cardiotokography in predictin baby's condition at birth. Br Med J 289 (1984) 1345

Received August 22, 1988. Revised March 6, 1989. Accepted March 15, 1989.

Prof. Dr. V. M. Roemer Kreiskrankenhaus Detmold Behringstraße 39 D-4930 Detmold West Germany 